\title{
Using of natural environment elements in formation of attractiveness of small town space
}

\begin{abstract}
The article discusses the role of natural space elements in formation of attractiveness of the urban environment of small towns. Meaningful use of natural elements is necessary for development of a strategy of formation of the urban space attractiveness and can become an important source of it. Natural surrounding also impacts the urban development structure itself, characteristics of architectural objects and spacial visual communication of a small town and its suburbs. Using available natural characteristics, as well as purposeful introduction of elements of wildlife and inanimate nature into the urban space has an essential impact on the increase of the number of visitors and tourists in the town and dissemination of information about it.
\end{abstract}

Keywords: urban space, natural environment, small town, architectural attractiveness.

Nature is an inseparable part of the urban environment. Natural elements, as well as other spacial objects, are full-fledged components of the process of formation of the architectural space and require a special attention. As the practice shows, the natural surrounding of architectural objects can either make them stand out by emphasizing their spacial characteristics or, vice versa, make them practically invisible and difficult for visual identification. Unfortunately, the peculiarities of natural environment are usually disregarded in the process of formation of the urban space, what frequently results in certain disadvantages, especially compositional and visual ones. Therefore, taking natural elements into account in the process of development of the concept of city attractiveness formation is essential and important.

Certainly, the first thing that comes to mind when we talk about natural elements in the city is their influence on the sanitary condition, ecology of a city, physical parameters that usually have essential impact on the quality of life. Natural characteristics and elements are integral components of introduction of principles of sustainable development and smart architecture in the process of elaboration of the urban development plan. However, in the nearest future these issues and principles will turn into main and essential requirements to the architectural environment and designing of objects. They are quite well represented in the modern professional literature [1] and do not fall within the scope of the present research. In this work, we would like to devote a special attention to spacial and visual characteristics, as well as conceptual aspects of natural elements in the small town space.
The role of natural elements in the small town space is analyzed herein by the example of small towns of Lviv region (Ukraine). This territory was chosen for several reasons. First of all, it contains a large number of small towns (with up to 50 thousand dwellers according to the state construction standards) [2]. This fact makes the issue of formation of the urban space attractiveness especially important, since all small towns are rather similar and there is a real threat of complete loss of their visual originality and distinctiveness. Secondly, the territory of Lviv region is rather diversified in terms of landscape and natural zones. There is a flat terrain and forest area on the north (Polissia). The Carpathian Mountains are located on the south. For this reason, the landscape is very interesting and varied that allows to analyze various options of compositional arrangement of the architectural space and using of different species of plants in the urban environment in the territory of one region [3]. Thirdly, this territory is also very interesting from the architectural and historical point of view. It is located in the border zone of East-European and West-European traditions of urban development arrangement of the city environment [4]. Panoramas of small towns include a large number of sacral objects be- 
longing to different confessions. Church buildings have their specific peculiarities and by visual interaction among themselves create specific town silhouettes. Besides, small towns of this region still bear visible traces of architecture of the Soviet period. Organization of their architectural environment is impacted by the specific attitude of the state leaders of that time to the nature in general and to the separate natural elements and methods of introduction of natural resources into the urbanized space. Later on in the period of the indepenthe urbanized sace. Latron, in the probendef lll town of to to the local enthusiasts due the lack of funds and cies in pressina towns. Unforty represented by professionals in the sphere of landscaping, architecture, landscape design, town planning and relied on their own visions of aesthetics of the environment, primarily solving local problems without taking care of the general visual image of a city. This situation lasted for quite a long time, and still exists in a number of small towns. Therefore, the current condition of urban landscaping and natural landscape objects in the town territory is mostly a result of spontaneous initiatives of town dwellers and local authorities. This situation led to appearance of several interesting aspects of usage of landscaping in the urban space. We can argue about negative or positive influence of such activity, however one can confidently say that it created a special character of the small town space that probably has a potential for additional direction of formation of visual attractiveness of the small town architectural space. Here we have to mention that these characteristics, present practically in all towns, can become a basis for the regional attractiveness. Then we will be able to say that small towns in a certain region have a specific attribute that allows visual identification of this region. For example, towns of Lviv region often have old cemeteries located in their central historical parts. They are mostly planted by trees, open for public access and serve as a peculiar kind of public gardens. Also, Eastern Christian churches located in these towns are always planted round by trees and encircthe town a a green area. Due to this fact, always visually accessible and is weakly exposed in the urban space. The same can be said about monumens that arten hard to identify visually, especially in summer, because they are hidden behind high green plantings.

A small town is a special type of settlement. On the one hand, it has characteristics of a city, and on the other hand - characteristics of the village. A city is an anthropogenic space that, at first glance, has little in common with the nature and generally subordinates the natural surrounding to the needs of comfort living of people. On the contrary, villages are very dependent on the natural environment and landscape. $\mathrm{Na}$ ture plays a leading role in these settlements and is critically important for their economic growth. In the context of this objective, the architecture plays a sort of secondary supportive role and frequently has a practical character. The role of the natural component in the architectural environment, as well as attitude of dwellers to natural elements, fundamen- tally differs in cities and in villages. A smal two opposite approaches to understanding of the nature. On the one hand, it has administrative and architectural characteristics of an urban settlement, what is especially noticeable in the building system of central parts of settlements. On the other hand, the majority of buildings in a small town is represented by prive houses with hown is represented impy private houses with household plots. It is int these plots are rather big an with a used not for decoration, but rather wh a practical purpose. In particular, the locals of small town in Lviv region often keep the toweep and goats, poultry. This makes the town space, especially its suburbs, visuIn this situation it is rather difficult to choose In this situation it is rather difficult to choose the correct concept of landscaping of the small town space. For example, the practicability of the tradition to arrange large parks and plant many trees on the central square of small towns, which became widespread in the Soviet times, now raises many doubts, because the majority of locals live in garde zones and have their own gardens. On the contrary, sometimes they would like to "go to town", to the urbanized space. Only a small number of people in small towns live in apartment houses, and their need in contacts with nature can be satisfied by arranging parks on much smaller territories (il.1, 2).

Architecture and architectural environment of settlements, including small towns, can be attractive in certain circumstances - i.e to be able to attract attention by their spacial and visual characteristics or conceptual meal and A source of such on conceptual meaning. can attractant pan be repentiful and pleasant atmosphere, but sometimes also by Attran enotionaly negative characteristics. Attractiveness of the unan space is especially important for a small town. This is explained both by status reasons and partially by economic considerations. Small towns often play a role of local cultural and administrative centers in the village surroundings. Therefore, the distinction of their architectural space from village settlements, their "urban" visual imag should be maximally emphasized. Also, the majority of small towns of Lviv region usually have specific historical monuments of architecture and places related to some historical events. However, due to economic and historical circumstances architectural building are mostly poorly maintained, and the history of a small town is usually little known not only

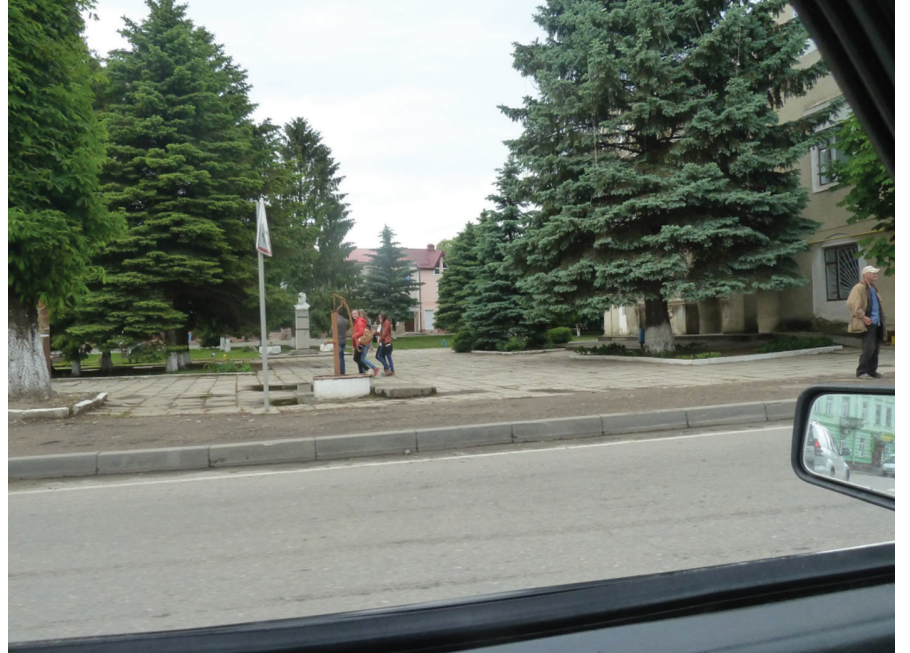

II. 1 Rudky. Trees on the central squares of small towns. So
II. 2 Rudky. Garden zones. Source: author's own materials

for town visitors, but even for its locals. In its turn, this impedes self-identification of townspeople, as well as preserva-
tion and development of special features of a town. The same tion and development of special features of a town. The same
economic circumstances make the issue of attractiveness of the urban space particularly topical for small towns. As opposed to big cities that have many sources of income, where the architecture plays an important role for their economic situation, but not a decisive one, exposition of the architectural environment of small towns often turns into the main source of their income. Namely the architectural environment is the first thing that travelers and tourists see, and namely contemplation of the architectural environment allows them to receive basic information about unknown settlements. Therefore, the problem of preservation of authenticity of historical small towns - objects of recreation and tourism is considered in many scientific researches, including in Poland (Anna Pavliak, Slavomir Kamosinski) [5, 6] and Ukraine (Mykola Bevz, Bohdan Posatskyy) [7, 8]. Traditionally it is believed that the the historical heritage of a town, including its architectural heritage (i.e. objects that correspond to the no tion of "high" culture based on their place in the hier the nopublic significance [O]), forms a foundation for formation of public significance [9]), forms a foundation for formation of inki, hic inchi, tary evidence of is civilizational and culturallegacy is subject to com 10$]$. place has architectural monuments of a corresponding level; and often many towns of some region have similar architectura objects. For example, small towns of Lviv region are mostly characterized by churches, cathedrals, residential stone houses of the 19th century located in central parts of towns. Therefore, it is difficult to shape the attractiveness of a certai town based only on these historical architectural buildings. Apart from that, concentration only on historical monuments and events throws into question the possibility of creation of an original image for relatively new towns that originated in the middle of the $20^{\text {th }}$ century as workers settlements or for those historical towns that were destroyed in the war time and rebuild again. In these and similar cases, the attractiveness of space should be purposely created from scratch or by using available non-standard objects that are disregarded from the point of view of classical tourist attractiveness and sometimes are even considered as an essential defect. In conditions of absence of usual traditiona atractants, we need to apply the principle of "flexibility in selection of attractants". The essence of this principle is to avoid a prejudiced attitude to various nonstandard options in seection of potential attractants among objects of the urban environment being guided by the presumption of innocence, and admit objects with spontaneous or negative attractiveness for consideration and analysis.

In both cases mentioned above, natural elements and green planting can foster formation of urban space attractiveness, and sometimes even act as self-sufficient, prioritized, visua and conceptual basis for formation of this attractiveness. For example, the town of Pidkamin takes its name from the stone rock ("kamin" in Ukrainian) located on the hill near the town. Pidkamin Festival is also organized here. So the rock became the main visual characteristic of the town. However, apart from this rock, the re is an old monastery, ancient cemetery and several chapels in Pidkamin that could become interesting attractants in other circumstances. Yet, historical objects are not a rarity for towns fet, historical objects are not a rarity for towns Yet, in 作

Let's make a conventional classification of various forms of presence of a natural component that directly or indirectly impacts the process of formation of the architectural space attractiveness of practically all settlements, including small towns. The first form of presence is the natural
landscape where the town is located. The 
rent. Due to the high popularity of the resort in the $19^{\text {th }}-21^{\text {st }}$ centuries, many new recreation centers, sanatoriums, hotels have been built and are still being built in the town. This turned the resort into a peculiar gallery of architecture of hotel and recreation objects. This situation is unique for a small town, especially in Ukraine. Also, as opposed to similar European resorts, historical authentic architecture in the town has not been preserved in full. There are also some small towns in Lviv region that originated as workers settlements near mines or electrical stations, for example, Hirnyk, Sosnivka, above-metioned Dobrotvir, Stebnyk. In Stebnyk, derricks for coal mining have created a unique peculiar town's silhouette that is maybe totally unaesthetic in the classical sense, but undoubtedly attractive and recognizable. Without them, the town would become visually unnoticeable (il.8). In our times, mineral resources in Lviv region are not so actively used and developed as before. However, traces of these past activities can present an excellent base of attractive objects for lovers of the history of technology. We can try to turn old mines into a good place for active recreation and training facilities for pupils or simply people interested in technologies.

\section{Conclusions}

For small towns, the problem of attractiveness of their architectural space is one of the high-priority issues that require permanent attention. Apart from formation of the attractiveness of a separate town, we can also support the general attractiveness of the architectural space of the region by developing characteristics that are present in the majority regional towns. Natural surrounding, starting from the geographical location of a town and ending with its landscaping, is a crucial component of the urban environment. Together with the architecture, natural elements create a town's silhouette and complete the urban architectural space. Impact of natural elements on the attractiveness of the architectural environment of small towns is exercised not only through their visual qualities, but also through their conceptual characteristics.

Natural resources that are present in the territory of a small town (healing waters, mineral resources) not only foster the development of the local economy and industry, but also play an important role in shaping of the urban space and town's panorama, thus facilitating formation of the conceptual and visual attractiveness of the architectural space. Natural elements, in all forms of presence of the natural component in a small town, have a decisive, although not always noticeable, impact on selection of the concept of formation of attractiveness of a certain urban space. Understanding of influence of this resource on visual and conceptual characteristics of the architectural environment will maximally facilitate its use in the process of project urban development activities.

\section{BIBLIOGRAPHY}

[1] Shchurova V. Mirkuvannia shchodo landshaftnoho ustroju miskyh terytoriy. Zasoby i pryjomy/Suchasni problemy arkhitektury ta mistobuduvannia,17'2007, KNUBA, Kyiv, s.155159

[2] DBN B.2.2-1-01. Mistobuduvannia, planuvannia i zabudova naselenyh punktiv

https://dnaop.com/html/32634/doc-\%D0\%94\%D0\%91\%D0 \%9D_\%D0\%91.2.2-1-01

[3] Kubiyovych V. Halychyna / Entsyklopedia Ukrainoznavstva, T.1, Naukove tovarystvo imeni T.Shevchenka u Lvovi, Lviv, 1993, s.344

[4] Dyda I. Ekologichni osnovy tradytsijnoyi ukrajinskoyi arhitektury, NU "Lvivska politehnika", Lviv, 2009, 332 p.

[5] Pawlak A., Problemy przestszenne wybranych malych miast polozonych w strefie turystyczno-wypoczynkowej Malopolski poludniowej / Architektura. Czasopismo techniczne, Wydawnictwo Politechniki Krakowskiej, 2-A/2009, zeszyt 10 rok 106, p. 117 - 124 https://suw.biblos.pk.edu.pl/resources/ i1/i8/i9/i6/r1896/PawlakA_ProblemyPrzestrzenne.pdf

[6] Kamosinski S. Historia miejsc jako produkt. Marketing terytorialny a dziedzictwo historyczne / Studia z zakresu prawa, administracji i zarzadzania UKW, 2013, p.2539 http://repozytorium.ukw.edu.pl/bitstream/handle/ item/415/S\% C5\% 82awomir\%20Kamosi\% C5\% 84ski. pdf? sequence $=1$

[7] Bevz M. Problemy regeneratsiji zapovidnyh terytorij istorychnyh mist / Visnyk Natsionalnoho Universytetu „Lvivska Politehnika" Arhitektura, 429, Lviv, 2001, p.146-155.

[8] Posatskyy B., Urbanistychnyj marketing istorychnoho mista / Visnyk Natsionalnoho Universytetu "Lvivska Politehnika" Arhitektura, 531, Lviv, 2005, p.101-103.

[9] Panchenko T. Turystychne seredovyshche: arhitektura, pryroda, infrastruktura, "Logos", Kyjiv, 2009, 176 p. 